doi: 10.52370/TISC21500SM

\title{
DOES EU FUNDING SUPPORT THE DIVERSIFICATION OF THE TOURISM OFFER IN SERBIA AS A RESPONSE TO THE COVID-19 PANDEMIC?
}

\author{
Snežana Maksimović ${ }^{1}$; Milan Stamatović ${ }^{2}$
}

\begin{abstract}
The aim of the paper is to answer the question of whether EU funding supports tourism in Serbia in a situation where this sector of the economy is facing astonishing figures of decline which is caused by the coronavirus. The paper is divided into two segments. The first part is based on the presentation of the possibility of diversification of the tourist offer in Serbia and the second part provides an overview of the literature related to EU funds. The research is interdisciplinary because it includes selective forms of tourism which united in a single tourist product can contribute to a tourist valorization of all areas and contribute as a response to the crisis caused by the pandemic. Contribution of EU funds can be seen through the connection between investment activities and the increase in tourist traffic. The special goal of the paper is education and raising awareness about the preservation of rural and eco areas, eco production and healthy lifestyles, which will contribute to the tourist offer and also a pleasure and enjoyment for visitors.
\end{abstract}

Key Words: EU funds, rural tourism, efficient management, development of tourism

JEL classification: $O 21, O 31, O 43, R 11, R 58$

\section{Introduction}

Tourism is an important factor in socio-economic and political development in many countries. It can contribute to positive socio-

\footnotetext{
${ }^{1}$ Snežana Maksimović, Assistent Professor of Business and Law Faculty, University MB, Belgrade, phone: 0601714333; galena.mcl@gmail.com

${ }^{2}$ Milan Stamatović, Full time Professor of Business and Law Faculty, University MB, Belgrade, phone: 0638736229, stamatovicm@sbb.rs
} 
economic and cultural progress but at the same time, it can lead to environmental degradation and loss of local identity. Due to the pandemic, tourism sector on a global level, even in Serbia, found itself under unprecedented pressure. Most domestic and international trips were canceled, leading to a significant reduction in revenue and liquidity problems for all those involved in tourism. Both travel companies and tourists have to deal with uncertainty. The World Tourism Organization estimates that international tourism has declined by $60 \%$ (World Tourism Organization - UNWTO, 2020b).

The European Commission estimates that there are 60-90\% fewer provisions in the EU than in previous years (European Union, 2020). Also, about 6 million jobs were lost. The loss of revenue is estimated at as much as $85 \%$ for hotels and restaurants and up to $85 \%$ for travel organizers and as much as $90 \%$ for cruise and air travel organizers (European Union, 2020). It is estimated that in Serbia, the total losses of the tourism industry reached two billion euros, and that $65 \%$ of workers who were not employed permanently left the tourism sector (Ralev, 2020). Tourism is an important factor in socio-economic and political development in many countries. It can contribute to positive socio-economic and cultural progress but at the same time, it can lead to environmental degradation and loss of local identity.

The pandemic crisis in the tourism sector is an opportunity to make tourism more resilient. Some of the recommendations are that is necessary accelerate the green and digital transition, more adequate transport and connectivity, as well as the diversification of the tourist offer.

The aim of this paper is to analyze the impact of the crisis in Serbian tourism caused by the COVID-19 pandemic and to consider measures to mitigate the negative effects of the crisis through diversification of tourist offer, as well as through review of available EU funds and their contribution to tourism recovery. The basic assumption from which the authors started in the research process is that the development of tourism depends on a large number of factors of economic and non-economic nature. Special assumptions are H1: tourism can play a significant role in the recovery of the country's economic development from the effects of the crisis and $\mathrm{H} 2$ : appropriate stimulus measures can accelerate the recovery of the tourism sector. 
Attention in this paper is focused on understanding how to manage a crisis caused by a pandemic and pointing out actions that can prevent crisis situations. The authors also set out to suggest the emergence of possible new risks, but also the prospects for further tourism development. Special attention is paid to possible measures that can contribute to mitigating the effects of the crisis on tourism.

\section{Changes in the form of tourist behavior as a consequence of the crisis}

The general definition of tourism means a travel and stay which are not based on residence and business. The presentation of natural and cultural resources, different traditions and ways of life are the starting point for the development of tourism. Various studies also point to a positive correlation between revenue growth and expenditure growth to meet tourism needs. But it is important to emphasize the sensitivity of tourism to natural and social events, so security is an important aspect of growth and sustainability of the tourist destination. The most pronounced decline in the tourism industry at the global level has just been recorded by the crisis caused by COVID-19. The crisis can be define as an "undesirable" or "unusual" situation that requires an immediate reaction and response of all interested parties to potential events that may cause negative effects on their business in the long run. Although there is no universally accepted definition of crisis, it can be concluded that three elements are present when a crisis occurs: a triggering event that causes significant change, or has the potential to cause significant change, perceived inability to cope with this change, and a threat to organizational survival (Henderson, 2007). Kathleen Fern-Banks defines a crisis as a "major" event with potentially negative consequences that affects a company or industry, as well as its target public, products, services or reputation (Keković \& Kešetović, 2006).

For Humble, the crisis is an "urgent situation in which all members of the group face a common threat" while Pauchant and Mitroff see it as "a disorder that physically affects the system as a whole and threatens its underlying assumptions" (Pauchant \& Mitroff, 1992, pp. 7-9). Contemporary authors argue that a crisis is any event that can escalate in intensity, come into the focus of media and government interest, disrupt normal business operations, and affect a company's image and profits (Helble \& Fink, 2020). Barton understands the crisis as "a larger and unpredictable event that has potentially negative results "(Henderson, 2007, pp. 1-3). Pearson and Clair define crisis as events of different probability of occurrence, but the consequences of which can significantly 
affect the business. Regardless of the various causes of the crisis and the effects that arise from it, decisions on how to deal with it have to been bringed quickly (Crandall et al., 2010).

Paul Hart defines the crisis as "an unpleasant event," which is a challenge for decision makers, tempting them to act in conditions of threat, time constraints and unpreparedness (Keković \& Kešetović, 2006). Crises can also be divided according to what is the cause of the crisis, natural or human activity. Crises caused by a natural event are, for example natural disasters: tsunamis, hurricanes, floods, earthquakes, while a crisis caused by human activities comes down to the fact that a certain event is caused by a human decision or activity. The negative effects of events caused by the human factor lead to a longer loss of confidence in the tourism sector and therefore have more negative effects on tourism than natural events. The question that tourists ask in the event of a political crisis, or a crisis caused by a pandemic like COVID-19, or an environmental crisis is "is it safe to travel?" And in terms of the functioning of the economic crisis, the fundamental question is changed and becomes"can we afford to travel?" Or "Do you want to spend on a trip?" (Kester, 2010).From the point of view of consumers (tourists), one can therefore distinguish between the types of crises in which there is a general feeling of insecurity for personal security and those where there is a feeling of insecurity related to income.

The crisis caused by the COVID-19 pandemic in tourism has also led to changes in the behavior of tourists. Today, the basic need of tourists is safety. In that direction, it is important to think about creating safe tourist destinations (Vujović et al., 2012). Strategically, this means ensuring security in the first place for visitors, but also employees in tourism and other activities, security in the environment and in general the creation of a positive image in this regard (Štetić, 2010). The systemic solution of every country which wants that its tourist destinations will be on the world tourist map is to create security strategies and risk management separately for each attractive location (Ural, 2016).

According to research by experts from the World Tourism Organization, domestic demand is expected to recover faster than international demand in terms of travel. Most expect signs of recovery to be seen in the last quarter of 2020, but mostly in 2021 (UNWTO, 2020a). Based on previous crises, it is expected that the travels for fun or personal reasons recover faster, especially trips to visit friends and relatives, as opposed to business trips. Any crisis situation is different and it is difficult to solve it using a 
simple formula. Foreach tourist destinations, governments with its departments for tourism and local government, must prepare action plans depending on their needs (Stamatović et al., 2020). Such plans can save valuable time, energy and other resources when a tourist destination is facing a crisis. Perceived risk can be greatly overcome in forming a real relationship in relation to the image of the destination, because it is crucial for destination promoters to understand the attitudes of potential visitors, to be able to define promotional activities that neutralize worries and change negative and strengthen positive perceptions (Rodríguez-Antón \& Alonso-Almeida, 2020).

The sustainability of a tourist destination largely depends on the ability to adapt to changes in tourist demand, to use all its resources efficiently and to include risk management in development planning. When offering certain destinations in the time before the COVID-19 epidemic, promoters of tourist destinations, through specific instruments of the marketing mix in relation to the set goals, promoted the basic elements for the evaluation of tourist attractions such as: natural factors (natural beauty, climate), social factors (cultural and historical monuments, festivals, fairs and exhibitions, features of local color, music), historical factors(remains of historical monuments, religion, historical events in the area), recreation (sports fields, thermo-mineral springs, night entertainment), shopping, infrastructure and accommodation facilities (Cooper et al., 2008).

The situation of the COVID-19 crisis has crystallized new principles on which the sustainability of tourism should be based. Firstly, all tourism participants will have to work very hard on establishing and implementing new hygiene standards. Secondly, understanding changes in tourist behavior is very important for the survival of tourist destinations. The crisis caused by the latest COVID-19 pandemic has led to numerous travel cancellations and it is necessary to analyze all the factors that affect it (Golets et al, 2020). This paper analyzed the basic processes of tourist behavior during the crisis in order to contribute to a deeper understanding the characteristics of them, which is essential to the recovery of destinations after the crisis. Following the literature, the authors, among other things, studied the differences in behavior depending on the national culture and based on that saw the differences in travel planning, style and duration of travel as well as sources of information about travel (Crotts, 2004).

The Japanese have been identified as a national culture that avoids uncertainty, while the Germans are more willing to accept insecurity and 
have a freer style of travel (Money \& Crotts, 2003). In numerous researches, the authors point out several concepts of risk perception when it comes to travel intentions, and among them, health risks stand out as the most influential.

Major crises such as SARS 2003 and bird flu in 2015 have just proven the claims on this topic, as they have had a greater impact on tourist behavior than the financial crisis. In the literature reviews for the COVID-19 pandemic, most influenced by travel intentions was the perception of health risk (Nazneen et al., 2020).

Some of the recent studies of tourists behaviour that were focused on the travellers individual characteristics show interesting observations of the author and that is the variable like age, education, experience in travelling determine and influence the person tendency for travel in the period of crisis (Khan et al., 2018). In the context of risk, researches show the relationship between the level of income and the tendency for travel, that is the persons with higher income spend their time more actively than others, which implies more trips among them (Đeri et al., 2014).

In Serbia, it is estimated that tourism is the biggest loser in the COVID-19 pandemic, and that the loss in that sector amounts to around one billion euros, according to the estimate of the relevant ministry (Ralev, 2020). There has been an increased interest of domestic tourists in rural tourism, and also that the capacities of households are limited. Accordingly, in the conditions of the pandemic, the priorities in tourism development are changing, so more work must be done in increasing the capacity and improving the content in rural tourism, that is the conclusion of all competent state participants in the tourism sector.

\section{Different scenarios for overcoming a crisis caused by a pandemic - a comparative analysis}

As a possible direction in order to overcome the crisis, the governments of various countries used a phased approach. In the first phase, the potentials of domestic tourism are analyzed and restrictions on travel within the country are suppressed when domestic tourism can be continued in compliance with strict legal protocols. Numerous governments have invested significant stimulus funds to support domestic tourism. For example, the Philippines has invested over $\$ 8.5$ million in a campaign to support domestic tourism (Talavera, 2020). 
The guiding idea for the campaign was the desire to travel, but for safety reasons domestic destinations should be suggested to domestic tourists. They based their analysis on comparisons of Filipinos going abroad in previous years and, on the other hand, visits by foreign tourists. The conclusion was incredible and indicated an exceptional of demand for tourism services if they would keep domestic tourists in the country (Helble \& Fink, 2020). The indicators are similar in other Asian countries.

UNWTO reports on the number of international arrivals and departures in almost all countries indicate that domestic tourism opportunities can overcome the impact of the crisis and bridge the gap created by the shortage of foreign tourists (UNWTO, 2019). Some countries have launched initiatives to establish green corridors with precise health protocols as a measure to overcome the crisis. Initially, these corridors would be established for business travelers.

When we talk about the diversification of the tourist offer as one of the scenarios for recovery from the crisis, it means completing or expanding the production (service) or sales program by including new products or services that differ from the previous ones. In marketing terms, this may mean differentiation, changes in the state of the relationship in tourist consumption, i.e. their quantitative and qualitative changes (Lutovac et al, 2016). It is the changes that encourage development processes that require the organization of the tourist offer in new adequate localities, in new destinations, with a built material basis and management that can organize the tourist offer (produce and commercialize tourist goods).Having in mind the benefits for the overall environment, in the future, the most successful tourist destinations are going to be the ones which make planes, do the organizing, implementation and control of marketing activities in correlation with the principles of sustainability which mean satisfactionof stakeholders on one hand and creating resources sustainability of that destination on other hand (Blumberg, 2005).

The change in tourist demand caused by the pandemic is directed towards domestic rural areas close to nature, which shows that there has been a change in our value system, a desire for a healthier, safer and more peaceful existence. The basic concept in the diversification of the tourist offer for the needs of rural and ecotourism is the "natural object" which can be considered as the smallest territorial indivisible unit. Recognizing the specifics of the tourist offer of a rural unit requires creativity and largely 
depends on social, cultural, economic and other factors of that environment.

\section{Diversification of the rural tourism offer as a response to the crisis induced by COVID-19 pandemic}

The crisis caused by the pandemic in Serbia showed tourist potential in domestic tourism. On a virtual panel on tourism that was held during the COVID-19 crisis (Center of Local Democracy, LDA Knjaževac, 2020) various tourist participants took part and tried to give answers to the observed trends and developments in tourism, as well as to the new situation.

The situation caused by the COVID-19 pandemic has crystallized some new principles on which the viability of tourism should be based, both locally and globally. One of the initiatives is green tourism, which is not a novelty, but now is an opportunity to systemic promote it through public policies (Center of Local Democracy, LDA Knjaževac, 2020).

The authors wanted to point out that the trend of diversification of tourist activities in rural areas has become almost a universal process due to the growth of tourist demand in these areas. This also affects the economic and social structure of these areas, where agriculture is not seen as a source of food, but as a necessary attraction that helps the specifics of the tourist offer (Santos et al., 2020).

Although Serbia is a country with a predominantly rural character and has great potentials of natural resources, this tourism sector is still insufficiently developed. The reasons for the slow development of rural tourism are mainly the limited number of entrepreneurs in rural areas, lack of adequate marketing activities, infrastructure and insufficient interest of local people, but also, insufficient motivation of unemployed tourist workers to work in the rural economy.

Sustainability in this tourism sector implies rural development while ensuring renewable resources, economic and environmental efficiency (Maksimović \& Stamatović, 2018b). Environment and ecology are one of the three key pillars of "sustainable development" (the second is the social aspect and the third is economic). Diversification of the offer of rural tourism in the economic sense means revitalization of the village, 
development of the local market for agricultural and non-agricultural activities in the village (Maksimović \& Stamatović, 2018a).

By promoting and developing different forms of rural tourism, especially within protected areas, Serbia can build the image of a unique ecodestination and stand out from the surrounding areas with such an offer. It is important to keep in mind that the terms "protected area" and "national park" are symbols not only of preserved nature, but also a well-planned area with the necessary infrastructure (Todorović \& Štetić, 2009, p. 151153). Supporting the identity of individual areas is compatible with the concept of specificity of tourism products, and this requires economic efficiency in resource management. Diversification of activities in rural areas has an economic and social effect and becomes a stimulus to development. This is the way of multiplied effect of tourism is expressed, which creates new values for the local community and affects its faster development.

\section{The role of $\mathrm{EU}$ funds in stimulating rural tourism}

Sustainable tourism requires significant financial resources. In that sense, the support of European Union funds is important. Special emphasis should be placed on the European Agricultural Fund for Rural Development, the European Regional Development Fund, the European Social Funds, and the Integrated Operational Program for Regional Development. When it comes to tourism, European funds support projects for the development of tourist destinations, support for cultural heritage or a variety of activities of a destination (Radu et al., 2015).

The interaction between the tourism destination and the natural environment might be recognized in two ways. Firstly, tourism subject to changes in demand uses natural resources enormously. Natural resources usually play the main part in a tourist product which makes it attractive and valuable. Secondly, tourist activities, among other economic activities, become a very destructive source of natural resources disturbing the nature and its resources in a process of using and the producing the tourist product or activity. In this way, massive tourism economy becomes the danger to itself because for the attractive offer it needs clear ecosystems, ecologically valuable, original and with extraordinary quality (Zielińska, 2008).

Additional incentives and loans are provided to farmers through national programs and financing plans for more diverse farm activities, to cover the 
costs to use the land for non-agricultural purposes, such as the creation of new circular paths for walking, cycling, horseback riding, including tourist infrastructure and required marketing and publicity (Vandić, 2016). The largest receptive and emitting markets for rural tourism in Europe are France, Germany, Austria, the United Kingdom and Italy, which together account for over $77 \%$ of the total rural tourism market in Europe (Talavera, 2020). There is a growing interest of tourists in rural destinations throughout the European Union, as well as increased interest in the specifics of certain areas and non-standard tourist products. In order to ensure that, it is necessary that the entities that provide tourist services cooperate with each other, and also with other entities that plan and direct this development at the macro level (Lutovac et al., 2016). Serbia faces various challenges in formulating its competitive offer in the field of rural tourism (Počuča \& Matijašević-Obradović, 2019).

However, what is important to point out at this time when the current crisis in the field of tourism is caused by the pandemic is that rural tourism is an opportunity for Serbia to position itself on the list of leading tourist destinations in the Balkans. Positioning strategies and activities should contain a combination of physical and spiritual elements that enable the positioning of authentic rural tourism that will reflect the authentic spirit of Serbia (Đorđević-Milošević \& Milovanović, 2012).

Serbia can participate in EU programs as a pre-accession member, provided that it respects the policies, mechanisms of functioning and application of the laws of the European Union. The rural development component is implemented according to Regulation 718/2007 and contributes to the achievement of several goals in the areas of rural development (Njegovan, 2016).

The availability of IPARD funds, which are aimed at achieving European standards and raising competitiveness, is also important for the development of rural areas in Serbia. Within the IPARD II program, the focus will be on support through national frameworks, partly due to the economic and social vulnerability of these areas on the one hand and on the other due to the huge potential and need for further development.

At the end of May last year, the Rulebook on IPARD incentives for diversification of agricultural holdings and business development was adopted, which specifies the users, conditions and documentation required for exercising the right to IPARD incentives (Instrument for Pre-Accession 
in Rural Development - IPARD, 2020). Caterers who want to improve their tourist offer or are just starting to engage in this activity in rural areas of Serbia, in this way will be able to receive support under IPARD Measure 7. Beneficiaries of this measure can be individuals, entrepreneurs and micro and small companies. For one project, which can be made up of several different investments, the users of IPARD Measure 7 will be able to return up to $65 \%$ of the investment amount from the IPARD fund and thus gain support between 5,000 and 300,000 euros per project (IPARD, 2020). The investments that are acceptable are diverse and refer to everything from the construction and reconstruction of accommodation facilities to the landscaping of the yard, construction of recreation grounds, space for tasting and selling food and drinks, purchasing bicycles, creating a website, etc.Funds for rural tourism resources are also supported through international donors such as GIZ (German agency for International Cooperation), the World Bank, the EBRD(European Bank for Reconstruction and Development)in the framework of cooperation between municipalities in the region, as well as cross-border financing.

In this way, the European Union (EU), in cooperation with the German Federal Ministry for Economic Cooperation and Development, in September 2020 awarded one million euros for the first 120 aid grants aimed at eliminating the consequences of the coronavirus pandemic in the tourism sector in Serbia "EU for cultural heritage and tourism" (Government of the Republic of Serbia \& Delegation of the European Union, 2021). The funds were intended for 120 projects, and the recipients of the aid are small and micro enterprises, family businesses, agricultural farms and companies from 12 cities and municipalities in eastern and southeastern Serbia. The largest number of grant beneficiaries, who received a grant of up to 10,000 euros per project, provides private accommodation for tourists (52 entrepreneurs), and camps, restaurants and providers of various catering services, boarding houses, hotels and hostels, tourist agencies, wineries and beekeepers. The project was part of a broader project the EU is implementing to help Serbia (Government of the Republic of Serbia \& Delegation of the European Union, 2021).

Various international organizations fund development projects in rural areas such as UNDP (United Nations Development Programme), FAO (Food and Agriculture Organization of the United Nations) Livestock Project in Sjenica, UNDP MIR (Municipal Improvement and Revival Programme) projects in Southern and Southwest Serbia, etc. are among the most successful contributions to rural development (Langan et al., 2010). 
Most of these projects have provided significant support to local communities and individuals, providing many examples of good practice on how small investments, education and cooperation can be used in other regions (Đorđević-Milošević \& Milovanović, 2012).

It is expected that in the future new basic approach of the EU towards rural development, a better future framework for financing initiatives from rural cross-border areas can be created. The Southeast European Permanent Working Group for Regional Rural Development is currently active in promoting and developing this concept, hoping to be able to support quality projects in cross-border rural areas that can best contribute to the integration of the Balkan region.

\section{Conclusion}

The crisis caused by the COVID-19 pandemic had a huge impact on the tourism sector, primarily on a significant drop in tourist demand. In this paper, the authors pointed out that in a pandemic, the priorities in the behavior of tourists are changing and that in accordance with that, it is necessary to analyze numerous uncertainties that affect the disruption of tourist spending. This confirms that tourism is affected by numerous factors of economic and non-economic nature, which directly causes certain quantitative changes. The authors emphasize the importance of noticing changes in the behavior of tourists during the crisis, in order to determine certain specifics depending on the set variables. Sociological and psychological factors are very difficult to express quantitatively, but numerous authors have indicated that it is possible to select variables and predict events. In that sense, certain groups of tourists adapted faster to the crisis by changing the scope, structure, quality, spatial dimension and duration of travel. Other tourist structures are characterized by the transition from foreign to domestic travel, often in the form of weekend tourism, eco-tourism and other alternative forms.

The diversification of tourist services is imposed in response to the crisis and thus confirms the hypothesis that tourism can play a significant role in the country's recovery from the effects of the crisis. The current crisis caused by the COVID-19 is an opportunity to make the domestic tourism more resilient and strengthen the green and digital transformation of tourism and support maintaining a rural destination to growth. 
The last segment of the paper points to incentive measures that can accelerate the recovery of the tourism sector, and actors in the tourism market are expected to be able to take advantage of these opportunities.

This proves the second assumptionon in this paper that the recovery of the tourism sector can be accelerated if appropriate incentive measures are taken. The rural community that is able to maintain proactivity and openness together with the support of national tourism actors is able to thrive by partnering with other stakeholders for their immediate environment and using external assistance in the best possible way. A precondition for the interest of a diverse tourist clientele for natural resources in Serbia is the establishment of interactive information flows in the wider market, including internationally. Accordingly, clearly defined strategic development goals are important, which will be accompanied by a hierarchy of decision-making at all levels. It largely depends on the human factor, because there is a lack of knowledge in development planning, as well as in the methodological harmonization and connection of strategic documents, so we need to work on that.

\section{References}

1. Blumberg, K. (2005). Tourism Destination Marketing-a Tool for Destination Management? A Case Study from Nelson/Tasman Region. Asia Pacific Journal of Tourism Research, Vol. 10, No. 1, 45-57.

2. Centar lokalne demokratije LDA Knjaževac, (2020), Virtuelni panel o turizmu и doba COVID-19 krize, http://www.lda-knjazevac.org/index.php/ vesti/182-virtuelni-panel-o-turizmu-u-doba-covid-19-krize, (14 February 2021).

3. Cooper, C., Fletcher, A., Fyall, A., Gilbert, D., Wanhill, S. (2008). Tourism: Principles and Practice, 4th Edition, Pearson Education Limited, Harlow, United Kingdom.

4. Crandall, W., Parnell, J., Spillan, J. (2010). Crisis Management in the New Strategy Landscape, Sage Publications, California, United States of America.

5. Crotts, J.C. (2004). The Effect of Cultural Distance on Overseas travel Behaviors. Journal of Travel Research, Vol. 43, No. 1, 83-88. 
6. Đeri, L., Armenski, T., Jovanović, T., Dragin, A. (2014). How income influences the choice of tourism destination?. Acta Oeconomica, Vol. 64, No. 2, 219-237.

7. Đorđević-Milošević, S., Milovanović, J. (2012). Održivi turizam u funkciji ruralnog razvoja, Fakultet za primenjenu ekologiju Futura, Univerzitet Singidunum, Beograd; Agroznanje, Vršac; FAO Budimpešta.

8. European Union, (2020), COVID-19 and the tourism sector, https://www.europarl.europa.eu/RegData/etudes/ATAG/2020/649368/EP RS_ATA(2020)649368_EN.pdf, (18 February 2021).

9. Golets, A., Farias, J., Pilati, R., Costa, H., (2020). COVID-19 pandemic and tourism: The impact of helat risk perception andintolerance of uncertainty on travel intentions, https://www.preprints.org/manuscript/ 202010.0432/v1, (15 February 2021).

10. Government of the Republic of Serbia, Delegation of the European Union, (2021), EU for Cultural Heritage and Tourism, https://www.euzatebe.rs/en/projects/eu-for-cultural-heritage-and-tourism, (18 February 2021).

11. Helble, M., Fink, A. (2020), Reviving Tourism amid the Covid 19 Pandemic, https://www.adb.org/sites/default/files/publication/633726/ reviving-tourism-amid-covid-19-pandemic.pdf, (17 February 2021).

12. Henderson, J. (2007). Tourism Crisis: causis, consequences andmanagement, Butterworth - Heinemann, Oxford, United Kingdom.

13. Instrument for Pre-Accession in Rural Development - IPARD, (2020), Plan raspisivanja IPARD poziva za 2020. godinu [Plan for announcing the IPARD call for 2020], https://ipard.co.rs/index.php/ipard-vesti-lat/19latinica/vesti/109-plan-raspisivanja-ipard-poziva-za-2020-godinu, $(18$ February 2021).

14. Keković, Z., Kešetović, Ž. (2006). Krizni menadžment i prevencija krize, Fakultet za bezbednost, Univerzitet u Beogradu, Beograd.

15. Kester, J.G.C. (2009), Tourism and Travel Update: Where to Next? MadridUNWTO, Google Schooar 
16. Khan, M.J., Chellinh, S., Ahmed, S. (2018). Intention to visit India among potential travellers: Role of travel motivation, perceived travel risk, and travel constraints. Tourism and Hospitality Research, Vol. 19, No. 3, 351-367.

17. Langan, H.R., Kačapor, Z., Mijačić, D., (2010), Terminal Outcome Evaluation of the UNDP Serbia Country Programme Document (CDP) 2005-2009, http://regionalnirazvoj.org/upload/Book/Document/2011_12/ UNDP_CPD_Evaluation_Report.pdf, (17 February 2021).

18. Lutovac, M., Jovanović, Z., Maksimović, S., Lutovac, B., Matić, M. (2016). Identification of Information Relevant for International Marketing. Interantional Research Journal, No.7, No. 49, 43-48.

19. Maksimović, S., Stamatović, M. (2018a). Risk management as a part of management public investment projects, International Scientific Conference International Scientific Conference-MEFkon 2018, Belgrade, 6, 231-248.

20. Maksimović, S., Stamatović, M. (2018b). The Conceptual Framework of the Approach in the Rural Tourism in Serbia. TISC - Tourism International Scientific Conference, Vrnjačka Banja, 3(2), 538-555.

21. Mc Clanahan, P. (2020). Europe's Patchwork Reopening. The New York Times, Series A, 11.

22. Money, R. B., Crotts, J. C. (2003). The effect of uncertainty avoidance on information search, planning and purchases of interantional travel vacations. Tourism Management, Vol. 24, No. 2, 191-202.

23. Nazneen, S., Hong, X., Ud Din, N. (2020). COVID-19 Crises and Tourist Travel Risk Perception, SSRN Electronic Journal, https://ssrn.com/abstract=3592321, (17 February 2021).

24. Njegovan, Z. (2016). Ekonomika turizma i seoskog turizma, Poljoprivredni fakultet, Novi Sad.

25. Pauchant, T., Mitroff, I. (1992). Transforminf the Crisis Prone Organization: preventing Individual, Organizational and Environmental Tragedies, Jossey Bass, San Francisco, California. 
26. Počuča, M., Matijašević-Obradovič, J., (2019). Analysis of Quantitative Indicators of Modern Tourism Development in the Republic of Serbia. $4^{\text {th }}$ International thematic monograph "Modern management tools and economy of tourism sector in present era", Belgrade, 493-507

27. Premović, J., Arsić, Lj. (2020). Socio-econimic aspect of tourism in the modern society, Zbornik radova Filozofskog fakulteta u Prištini

28. Radu, A.C., Dobrecsu, A.I., Orzan, M.C., Boboc, L. (2015). The Importance of European Funded Projects for the Development of a Tourist Destination Case study - North-West Region of Romania (North Transylvania). Journal of Economic Studies and Research, Vol. 2015, 1-5.

29. Ralev, R. (2020), Serbia expects $300 \mathrm{mln}$. damage to tourism for coronavirus crisis, https://seenews.com/news/serbia-expects-300-mlneuro-damage-to-tourism-from-coronavirus-crisis-697548, (17 February 2021).

30. Rodríguez-Antón, J.M., Alonso-Almeida, M. (2020), COVID 19 Impacts and Recovery Strategies: The Case of the Hospitality Industry in Spain, https://www.mdpi.com/2071-1050/12/20/8599, (17 February 2021).

31. Santos, M., Gonzales, M., Haegeman, K., Rainaldi, A. (2020), Behavioural changes in tourism in times of COVID-19, https://s3platform.jrc.ec.europa.eu/documents/20182/392265/Behavioural +changes+in+tourism+in+times+of+COVID-19/059ea958-6696-467a8507-2e8617a4b86a, (18 February 2021).

32. Stamatović, M., Maksimović, S., Sućeska, A. (2020). Risk Management as a part of the Internal System of financial controls -practise in the public sector in Serbia. Economy and Market Communication Review., Vol. 10, No. 2, 431-451.

33. Štetić, S. (2010). Risk Management in rurual tourism. Economics of agriculture, Vol. 57, No. SI-2, 359-365.

34. Talavera, C. (2020), DOT Pushes through Campaign to Encourage More Domestic Tourist Philstar Global, http://www.tourism.gov.ph/ news_features/NewCOVID-19Variant.aspx, (14 February 2021). 
35. Todorović, M., Štetić, S. (2009). Ruralni turizam, Geografski fakultet, Beograd.

36. Ural, M. (2016). Risk Management for Suistainable Tourism. European Journal of Tourism, Hospitality and Recreation, Vol. 7, No. 1, 63-71.

37. Vandić, V. (2016). Podrška i podsticaj ruralnog turizma u okviru IPARD II programa Republike Srbije, Bios fond, Donji Milanovac.

38. Vujović, S., Cvijanović, D., Štetić, S. (2012). Destinacijski koncept razvoja turizma, Institut za ekonomiku poljoprivrede, Beograd.

39. World Tourism Organization - UNWTO, (2019), International Tourism Highlights, https://www.e-unwto.org/doi/pdf/10.18111/9789284421152, (14 February 2021).

40. World Tourism Organization - UNWTO, (2020a), International tourist arrivals could fall by $20-30 \%$ in 2020, https://www.unwto.org/news/ international-tourism-arrivals-could-fall-in-2020, (13 February 2021).

41. World Tourism Organization - UNWTO, (2020b), World Tourism Barometer, https://www.eunwto.org/doi/epdf/10.18111/wtobarometereng. 2020.18.1.6, (12 February 2021).

42. Zielińska, A. (2008). European Union founds for sustained tourism. Journal of Scientific Papers Economics \& Sociology, Vol. 1, No. 1, 1-8. 